\title{
Informational Consequences of Mandatory IFRS Adoption in China
}

\author{
Archana Patro \\ Indian Institute of Management Rohtak, India \\ E-mail: archana.patro@iimrohtak.ac.in
}

Received: August 14, 2018

doi:10.5296/ijafr.v8i3.13499
Accepted: October 3, 2018 Published: October 8, 2018

URL: https://doi.org/10.5296/ijafr.v8i3.13499

\begin{abstract}
In China, International Financial Reporting Standards (IFRS) have become mandatory for listed firms in 2007. While earlier research on "voluntary" adopters has provided valuable insights on the impact of IFRS disclosure, these results cannot be generalised in a mandatory setting. We expect effects from mandatory IFRS adoption to be different from those documented for voluntary IFRS adopters since the former group is essentially forced to adopt IFRS. The empirical model, relating to stock price synchronicity with adoption of IFRS, and other firm-specific control variables were analysed using both univariate and multivariate techniques. Different types of panel data estimates were used and compared so as to interpret the results with the best-suited parameters for different data sets for different markets. Studying data covering the period from 2001-2013, the present study examines whether mandatory adoption of IFRS reduces Stock Price Synchronicity for Chinese firms. The empirical results show that IFRS adoption improves information environment by the capitalization of firm-specific information into stock prices, thereby reduces the Stock Price synchronicity. The paper further examines if the information impact was homogeneous across industries. This pattern of decrease in stock price synchronicity after adoption of IFRS is different for different industries taken for analysis. Aerospace \& Defense, Automobiles Beverages, Metals \& Mining, Retailer\& Real Estate Operations have reduced synchronicity but other industries such as Biotech, Electric utilities, Electronic, Leisure products, Renewable energy and Telecom have increased synchronicity. For these industries, the low reliance on market wide information makes reasonable economic sense because they have relatively low demand elasticity. Hence, in demand inelastic industries, future price sensitive factors remain constant and so a changed IFRS accounting regime has little marginal impact. This study provides a different methodological approach by concentrating on Industry wide information
\end{abstract}


effects from the mandatory adoption. These findings have important implications that apply not only to China, but also to other emerging and transitional economies such as India where IFRS is yet to be mandated. Moreover it will help regulators, academicians and practitioners to assess the informational benefit of adopting IFRS.

Keywords: IFRS, Stock price synchronicity, Mandatory adoption, China

\section{Introduction}

This paper seeks to answer whether Mandatory adoption of IFRS (International Financial Reporting Standards) affect the Stock price synchronicity for listed firms in China. All listed firms in China are now required to report under IFRS from the year 2007. This new set of standards has been introduced by International Accounting Standards Board (IASB) in 2001 aiming at international accounting harmonisation throughout the world. Most of the European Countries have adopted IFRS on or after 1 January 2005. Other major Asian countries have recently started the transition or are in the process of making it mandatory in near future. After the introduction of IFRS, a stream of literature have observed the consequences of adopting IFRS; they have proved that reports under IFRS are of higher quality compared to the reports prepared under National GAAPs in different countries. The present paper contributes to this stream of literature by focussing on the Impact of IFRS adoption on Stock Price synchronicity in China. Stock Price synchronicity is an important issue in accounting and finance as it has been shown to be closely related to economic development and stock market stability. It also has implications for asset pricing, as well as for noise traders and the investors. Corporate governance mechanisms are more effective when Stock Price synchronicity is lower (Morck et al. 2000). Stock Price synchronicity can drive the value of a stock from its fundamental value. This over- or under-valuation of stocks can have a negative affect for the overall equity market (Roll, 1988). Investors are exposed to greater risk as Stock Price synchronicity increases (Campbell et al. 2001). The proponents of IFRS say that after adopting IFRS in financial reporting, corporate disclosures increase which help investors to collect and trade on firm specific information. Consequently stock price now becomes more informative. With this assumption we expect IFRS adoption to lead a decrease in Stock Price synchronicity.

But some literatures argue that a single set of standards may not be suitable for all settings and thus may not uniformly improve value relevance and reliability due to differences among countries (Soderstrom \& Sun, 2007). Empirical studies have also proved that quality change after the adoption of IFRS in different countries. One of the internationality dimensions is that the standard is not closely aligned with the economic or political institutions of any particular nation (Chua \& Taylor, 2008), so there are arguments for assessment of IFRS practice on a country-by-country basis (Nobes, 2006). The International Accounting Standards Committee (IASC) Foundation has documented the "need to have an understanding of the impact of IFRS as they are adopted in particular regions" (The International Accounting Standards Board [IASB], 2004, para. 93). China is the world's largest emerging and growing economy; it is attracting investors around the world (Lin \& Liu, 2011). Hence testing the relation of IFRS adoption and Stock price synchronicity is very important in this context. Also the study done by Morck et al. (2000) has demonstrated that 
developing countries are less mature and have more stock price synchronicity as compared to the developed countries. Hence the present study is motivated towards assessing the benefits of IFRS adoption with respect to reducing synchronicity for Chinese firms. The study can have several contributions as we believe. First, we concentrate on one specific country China in an emerging economy whereas earlier studies on the similar trend have focused specially on Europe and other developed countries. Second this study provides a different methodological approach by concentrating on Industry wide information affects from the mandatory adoption of IFRS. According to the analyses of Hawksworth and Tiwari (2011), China is expected to surpass the US as the world's largest economy (measured by GDP at purchasing power parity (PPP)) some time before 2020. As a large transitional economy with a mixture of state-sponsored and market-oriented capitalism, China's experience with IFRS convergence allows useful inferences for the other members of the E7 emerging economies: India, Brazil, Russia, Indonesia, Mexico and Turkey. These considerations explain why the impact of IFRS convergence in China is an interesting topic for academics, practitioners and regulators worldwide. The rest of the paper is organised as follows. Section 2 describes the Literature Review. Seection3 illustrates the methodology adopted. Section 4 presents the analysis of the results and Finally Section 5 concluded the paper with discussion of the results and implications.

\section{Literature Review}

Empirical evidence from the literature indicates positive consequences associated with the mandatory adoption of IFRS. Dasgupta, Gan, and Gao (2010) provided evidence that share price involves more firm-related true information after IFRS adoption. Beuselinck, Joos, Khurana, and Vander Meulen (2010) examined the impact of mandatory IFRS adoption on stock price informativeness across $14 \mathrm{EU}$ countries, and provide evidence for the decrease in stock price synchronicity regarding IFRS adoption, and a subsequent increase in stock price synchronicity post IFRS adoption; they interpret their results to suggest that IFRS disclosures reveal new firm-specific information during the adoption period but, subsequently, surprise for future disclosures diminishes. The same concept of subsequent increase in synchronicity post IFRS adoption has been proved by Bissessur and Hodgson (2012) with a study on a selected sample of firms in Australia. Santana, Sarquis, Lourenço, Salotti, Murcia,(2014) provide evidence for IFRS adoption in Brazil has reduced stock price synchronicity and, consequently, increased the efficiency of resource allocation and potential portfolio diversification.The firms that are cross-listed in other countries, such as on U.S stock exchanges, show an improvement in their informativeness due to the additional disclosures and scrutiny requirements for cross-listings (Fernandes \& Ferreira, 2009). Kim and Shi (2012) examine the consequences of voluntary IFRS adoption for firms in 34 countries and document that stock price synchronicity decreases following voluntary IFRS adoption. Further, the study provides evidence that synchronicity is lower for IFRS adopters as compared to non-adopters; decrease in synchronicity due to IFRS is found only for firms that have a higher analyst following. These authors have taken into account only those firms in their sample that adopted IFRS voluntarily. They also mention that the process of IFRS adoption might not be the same in all countries; a more pronounced synchronicity-reducing 
effect is found in countries with a weaker institutional environment. Studies (Gul, Kim, \& Qiu, 2010; Jin \& Myers, 2006) support the fact that countries with poor investor protection, low corporate governance, and a less-developed financial system have higher synchronicity as compared to countries with strong institutional environments. Going further, Loureiro and Taboada (2012) suggest that the improvement of stock price informativeness is more significant for voluntary IFRS adopters than for mandatory IFRS adopters. The impact of IFRS adoption also depends on the level of the enforcement of laws in a country (Landsman, Maydew, \& Thornock, 2012). Relating to sample emerging markets, prior research by Morck et al. (2000) gives empirical evidence that stock returns are more synchronous in emerging economies than in developed economies, although the causes remain unclear. Moreover, Fernandes and Ferreira (2009) find that the enforcement of trading laws improves stock price informativeness, but only in developed markets. Complementary to the above findings some studies fail to find strong evidence that IFRS improve the information set of investors, and find limited or no capital market benefits for mandatory adopters. In 1995, taking cross-sectional data on 37 countries, Morck et al. (2000) argue that taking accounting standards as a parameter does not explain stock price co-movements. Daske, Hail, Leuz, and Verdi (2008) show that capital market benefits around mandatory adoption of IFRS are unlikely to exist primarily because of IFRS adoption. Dasgupta et al. (2010) argue that in an efficient and transparent market, accessing firm specific information is less expensive which helps to anticipate the future firm specific events. So when the event, in this case IFRS adoption, actually happens in the future in such markets, the markets will not react as expected. This in turn could make the return synchronicity even higher. Wang and Yu (2009) conducted a 10 -year study in 44 countries and found no evidence of any significant relation between IFRS adoption and stock price synchronicity. This suggests that the adoption of high quality accounting standards, like IFRS and U.S. GAAP, is not related to the information content of stock prices; the adoption of such accounting standards is helpful only in countries with proper reporting incentives. To sum up, the evidence from literature on synchronicity and IFRS adoptions gives mixed results, which motivates us to test this relation in an Asian country i.e. on China context, where studies are limited.

From the literature following hypothesis has been developed and has been tested in this paper.

$\mathrm{H}_{1}$ : IFRS adopters in China experienced a significant decrease in Stock price synchronicity after the adoption of IFRS as compared to the period before the adoption

H2: IFRS adopters in China experienced a significant increase in Stock price synchronicity after the adoption of IFRS as compared to the period before the adoption

\section{Research Methodology}

\subsection{Sample Selection}

The main analysis is based on a sample of 3600 firm-year observations of Chinese firms listed in either the Shanghai or Shenzhen stock exchanges over the period 2001 to 2013. The years before and after 2007 are classified as the pre- (2001-2006) and post-IFRS (2008-2013) 
convergence periods respectively. The sample excludes financial firms. The accounting regulations applicable to a Chinese listed firm depend on the type of security issued: A-shares, which can only be owned and traded by Chinese citizens and B-shares, which can be owned and traded by foreigners, Chinese citizens, or both (Peng et al., 2008). Firms that issue A-shares are required to comply with Chinese domestic accounting standards that have gone through changes to converge with IFRS. Although no voluntary adoption of IFRS is allowed, firms that issue B-shares are mandated to comply with IAS/IFRS. Those that issue both Aand B-shares are required to issue two sets of annual reports, one with Chinese standards and the other with IFRS (Penget al., 2008). Thus, since January 1, 2007, the effective date of the 2006 new accounting standards, all listed A-share firms are mandated to follow substantially IFRS-convergent accounting standards. (Lee et al. 2013), the researcher look at how the stock price synchronicity among China's listed firms changed following the introduction of IFRS-converged CAS in 2007.

This policy created a natural experiment. The issuers of A and B shares were similar to the treatment and control groups in a controlled experiment - they have been subject to the same influences in almost every way, apart from reporting requirements. Changes to the synchronicity of stock after 2007 can be calculated for both the 'treatment' and the 'control' group. Any changes that are significantly more pronounced among issuers of 'A' shares than issuers of ' $\mathrm{B}$ ' shares can be attributed to IFRS convergence. The synchronicity got reduced only in the treatment group: the A-share issuers that did not have to make IFRS-converged disclosures before 2007. In the control group (B-share issuers that had to make IFRS-converged disclosures even before 2007), synchronicity remains almost same as they were previously. This means that investors in Chinese firms have found stock price to be more informative since IFRS convergence and this change is hard to attribute to any factor other than convergence itself. Having established the overall effect of IFRS convergence on the stock price synchronicity, the researchers then focused on the treatment group of A-share issuers in order to understand which companies started producing more informative accounts after convergence.

\subsection{Data Measurement}

To determine the Impact of IFRS adoption on Stock Price synchronicity, the following model were examined as represented by equation (1) below-

$$
\begin{aligned}
\text { SYNCHi, } \mathrm{t} & =\alpha 0+\beta_{0} \mathrm{ADIFRS} \Upsilon_{\mathrm{j}} \mathrm{IND}_{\mathrm{j}+} \beta_{1} \log (\mathrm{MCAP})_{\mathrm{i}, \mathrm{t}}+\beta_{2} \mathrm{LEVG}+\beta_{3} \mathrm{FSale}+\beta_{4} \mathrm{CL} \\
& +\beta_{5} \mathrm{HERF}_{\mathrm{i}, \mathrm{t}}+€_{\mathrm{i}, \mathrm{t}}
\end{aligned}
$$

Where,

SYNCH i, $\mathrm{t}=$ Stock Price synchronicity of the firm with respect to industry and market ADIFRS = A dummy variable for adoption of IFRS, taken as 1 if a firm adopted IFRS, else taken as 0 .

IND $\mathrm{j}=$ Type of industry 
MCAP $=$ Market capitalisation of the firm taken as a proxy for firm size

$\mathrm{LEVG}=$ Leverage ratio

$\mathrm{F}$ Sale $=$ Foreign sales in percentage

$\mathrm{CL}=\mathrm{A}$ dummy variable for the Firm's exposure to foreign capital markets

HERF $=$ Herfindahl index as a proxy for industry-level concentration.

All variables in model (1) are discussed in more detail below .Taking the reference of work done by (Art Durnev, Li, Mørck, \& Yeung, 2004; Piotroski \& Roulstone, 2004) the stock returns synchronicity is computed for each firm in the sample. The dependent variable Stock Price Synchronicity is calculated from the following equation (2)-

$$
R_{i, w}=a+b_{1} M R_{i w-1}+b_{2} M R_{i, w}+b_{3} I_{i, w-1}+b_{4} I_{i, w}+€_{i, w}
$$

Where,

$\mathrm{R}_{\mathrm{iw}}=$ Weekly Return for a firm

$\mathrm{MR}_{\mathrm{i}, \mathrm{w}}=$ Market return for the current week

$\mathrm{MR}_{\mathrm{iw}-1}=$ Market return for the previous week

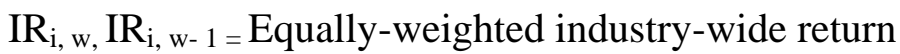

Firm-level weekly return is regressed over the current years and previous years market return along with current and previous week' s equally weighted industry return (Note 1).where Industry Returns, IR, is calculated from the formulae below-

$$
\mathrm{IR}_{\mathrm{iw}, \mathrm{t}}=\frac{\sum \mathrm{k}_{\text {䋿 }}\left(\mathrm{r}_{\mathrm{kw}, \mathrm{t}}-\mathrm{r}_{\mathrm{jw}, \mathrm{t}}\right)}{\mathrm{j}_{\mathrm{i}}-1}
$$

Where $r_{k w, t}$ the return is for a firm in a particular industry and $J_{i}$ in the denominator is the number of firms in the same industry during that week

After getting the value of $\mathrm{R}$ from equation (2), it is taken as the input for the synchronicity calculation formulae as represented by equation (4) below

$$
\mathrm{SYNCH}=\log \left(\frac{\mathrm{R}^{2}}{1-\mathrm{R}^{2}}\right)
$$

R-square measure is the most widely accepted measure in literature for calculating synchronicity. This measure is able to calculate the individual firm-level synchronicity, and if country-level synchronicity value is required, the individual firm-level synchronicity values are simply averaged over. This model measures the synchronicity by correlating the firm-level weekly stock return data with market return data. A higher value of R-square reflects higher synchronicity. Exhibit 1 illustrates the control variables that are expected to 


\section{Mll Macrothink}

International Journal of Accounting and Financial Reporting

ISSN 2162-3082

2018, Vol. 8, No. 3

impact synchronicity and the measurement models used by various researchers in calculating stock price synchronicity. As evident from the literature the most popular measure for synchronicity is R square measure. Hence, we adopted the same in the present study. Further Stock price synchronicity depends on several factors as identified by various authors in their research. The principal factor behind high trading time variance is private information (Roll, 1988). Greater volatility of stock returns was found during trading hours, and variations in stock prices are reflected by firm related information (Roll, 1988). Stock price synchronicity is found to be negatively influenced by a country's geographical size, whereas it is positively related to GDP (Morck et al., 2000). Countries with low geographical size are mostly unstructured in terms of their financial markets, which leads to low growth (Levine \& Zervos, 1998). Countries with fewer firms listed in the stock market are seen as having high volatility and high stock price synchronicity (Morck et al., 2000)

MCAP has been used as a proxy for firm size .It is assumed that large size firms would have low synchronicity due to expectations for better disclosure. But at the same time firm size could also negatively influence stock return synchronicity because some investors may not get information for small size firms as it may be very costly (Kelly, 2005). Returns on large stocks are more synchronized with the market relative to returns on small stocks (Dasgupta et al., 2010; Fernandes \& Ferreira, 2008; Kelly, 2005). Hence the sign prediction for MCAP with synchronicity is conflicting in the regression model. Similarly other control variables that are taken for our empirical model may have positive or negative association with stock price synchronicity which are tested by the empirical analysis in the present study. Type of Industry (IND) - a firm belongs to may have a different impact on synchronicity(Piotroski \& Roulstone, 2004). LEVG -Leverage, Firms with higher leverage level are associated with lower stock price synchronicity(M. J. Gordon \& Shapiro, 1956) (Li, 2010) F Sale -Percentage of Foreign sales Increase in sales outside home country leads to less Stock Price Synchronicity(Gul, Kim, \& Qiu, 2010; Kim \& Shi, 2012a) CL- Cross listed. Firms that are cross-listed on Foreign Stock exchanges have to prepare financial reports in accordance with their regulations and are required to follow other more stringent governance rules such as the rules on board structure and executive compensation resulting in decrease in synchronicity Gul et al., 2010; Kim \& Shi, 2012) HERF-Herfindahl index (+) The more concentrated an industry is, the more the synchronicity (Piotroski \& Roulstone, 2004)

Exhibit 1 . Summary of literature on stock synchronicity measures and explanatory variables

\section{Literature}

Morck et al., 2000

Number of stock listed in the market, property rights, good governance index, GDP, GDP growth variance, and geographical size.

\section{Measure}

R-square and

Classical

Durnev, Morck, \& Yeung (2004)
Size, liquidity, leverage, advertising expenses, R-square R\&D expenses, firm-specific stock returns. 
Chan \& Hameed, Synchronicity, analyst coverage, size, trading R-square 2006 volume, firm capitalisation.

Skaife, Gassen, \& R\&D expenses, ROA, analyst forecast earnings. LaFond, 2006

R-square and

Zero-return

Sarod, 2008

Rule of law, inflation, corruption and geographical size synchronicity, industry fixed effects, number of analyst revision.

R-square,

Zero-return and

Classical

Beuselinck et al., Synchronicity, industry fixed effects, number of

R-square 2010 analyst revision, institution holding, market value of equity, Herfindahl index, inflation-adjusted GDP.

Li, 2010

Trade openness, capital openness, good R-square governance, Asian crisis dummy, real crisis dummy.

Kim \& Shi, 2012 Synchronicity, size, leverage, growth, sale, Big 4 R-square audit, ROA, GDP.

Bissessur \& Size, Herfindahl index, stock volatility. R-square Hodgson, 2012

Horton, Serafeim, Firm size, loss, ADR, analyst coverage, absolute R -square $\&$ Serafeim, 2013 accruals, experience, CF forecasts.

\section{Data Analysis and Discussions}

To determine the impact of IFRS adoption on firms in China, the hypothesis as proposed in the study has been tested by various statistical tools such descriptive statistics, correlation and panel data regression which are described in detail below.

\subsection{Descriptive Statistics}

Descriptive statistics are presented in Table 1. Period 1 refers to the calendar years 2001-2006 when IFRS had not been adopted whereas period 2 refers to the year 2008-2013, when IFRS was adopted. The mean and median of stock price synchronicity for China are 0.48623 and 0.49157 respectively, for the sample, which are much higher than those for US firms. For example, (Piotroski \& Roulstone, 2004) who measure the synchronicity for US firms found the mean and median of synchronicity to be -1.742 and -1.754 . This indicates firms in U.S have less synchronicity than firms in China. For the sample of Chinese firms 


\section{Ml Macrothink}

International Journal of Accounting and Financial Reporting

ISSN 2162-3082 2018, Vol. 8, No. 3

stock price synchronicity exhibits a sudden decreasing pattern in the year 2008-2013 with a mean value of 0.2421615 when mandatory IFRS adoption became effective as compared with a value of 0.730303 in the year 2006-2008 when firms in China were reporting under National GAAP. A look at the control variables reveals, the mean value for HERF is 5694.33. The mean value of market capitalisation is 5.98109. The mean value for total debt is 27.2683. Along with SYNCH, other control variables like MCAP, Percentage of Foreign Sales, Total Debt to total Assets and HERF also exhibit regular change in patterns over time. Thus, it is essential to control these variables to rule out different explanations for observed patterns. Results from the descriptive analysis suggests that stock price synchronicity went down in the year when mandatory IFRS adoption became effective or in other words the stock price in formativeness increases. This pattern of decrease in the SYNCH value prevails for almost majority of industries in our sample as represented in Table 2. Exception is only for firms which belong to Aerospace \& Defence industry where synchronicity increases after IFRS adoption.

Table 1. Descriptive statistics IFRS and stock price synchronicity - China

\begin{tabular}{|c|c|c|c|c|c|c|c|c|c|}
\hline \multicolumn{4}{|c|}{ Total Sample } & \multicolumn{3}{|c|}{ Before IFRS } & \multicolumn{3}{|c|}{ After IFRS } \\
\hline & $(2001-20$ & 13) & & $(2001-2$ & & & $(2008-2$ & & \\
\hline Variables & Mean & Median & Stand.dev. & Mean & Median & Stand.dev. & Mean & Median & Stand.dev. \\
\hline SYNCH & 0.48623 & 0.49157 & 0.57965 & 0.7303 & 0.75814 & 0.50857 & 0.24216 & 0.25253 & 0.54407 \\
\hline MCAP & 5.98109 & 5.78717 & 0.88922 & 5.82877 & 5.64201 & 0.89666 & 6.13341 & 5.95979 & 0.85866 \\
\hline$L E V$ & 27.2683 & 23.535 & 21.9384 & 28.5901 & 25.45 & 22.6792 & 25.9464 & 20.955 & 21.1839 \\
\hline FSALE & 6.69988 & - & 18.5799 & 6.91483 & - & 18.5028 & 6.48492 & - & 18.7317 \\
\hline$C L$ & 0.275 & - & 0.44745 & 0.275 & - & 0.44839 & 0.275 & - & 0.44839 \\
\hline$H E R F$ & 5694.33 & 4973.65 & 2114.16 & 5713.76 & 5255.06 & 2096.61 & 5674.9 & 4945.02 & 2140.18 \\
\hline
\end{tabular}

Notes: SYNCH -Synchronicity of firm-level stock returns with market-wide and industrylevel returns. ADIFRS refers to Adoption of IFRS, dummy variable equal to 1 if a firm adopts IFRS and 0 otherwise. MCAP (Market Capitalisation) -the market value of equity of the firm at the beginning of the calendar year; $L E V G$ (Leverage) - the ratio of the long-term and short-term debts to Total Assets; F SALE - Percentage of foreign sales. CL -A dummy variable for a firm's exposure to foreign capital markets; $H E R F$-A revenue-based Herfindahl index of industry-level concentration. 


\section{Macrothink \\ International Journal of Accounting and Financial Reporting

Table 1.1 Analysis of variance for synchronicity and ADIFRS-China

\begin{tabular}{llllll}
\hline Source & SS & df & MS & F & Prob > F \\
\hline Between groups & 14.296927 & 1 & 14.2969279 & 64.55 & 0.0000 \\
Within groups & 66.004307 & 298 & 0.22148993 & & \\
Total & 80.3012 & 299 & 0.3359884 & & \\
\hline
\end{tabular}

Bartlett's test for equal variances: $\operatorname{chi} 2(1)=0.5392 ;$ Prob $>\operatorname{chi} 2=0.463$

F value is significant and from Bartlett's test for variance is not significant. Our results indicates there is a staitistically significant difference betweeen the means of the synchronicity for each of the groups of ADIFRS (Brefore IFRS adoption \& After IFRS adoption)

Table 2. Descriptive statistics of synchronicity measures by different period of adopting IFRS over different type of industries-China

\begin{tabular}{|c|c|c|c|c|}
\hline Industry Name & ADIFRS & Mean & Median & Stand.dev \\
\hline \multirow{3}{*}{ Renewable Energy } & Before & 0.833364 & 0.6253501 & 0.6452223 \\
\hline & & & & \\
\hline & After & 0.707691 & 0.9150191 & 0.8121473 \\
\hline \multirow{2}{*}{ Aerospace \& Defence } & Before & 0.473175 & 0.3277589 & 0.4094718 \\
\hline & After & 0.645814 & 0.5769151 & 0.2505221 \\
\hline \multirow{2}{*}{ Insurance } & Before & 1.196423 & 1.2312100 & 0.5182468 \\
\hline & After & 0.386426 & 0.5354699 & 0.7849097 \\
\hline \multirow{3}{*}{ Beverages } & Before & 0.713020 & 0.7511978 & 0.3880884 \\
\hline & & & & \\
\hline & After & -0.01632 & -0.2072953 & 0.5984141 \\
\hline \multirow{3}{*}{ Metals \& Mining } & Before & 0.759037 & 0.7804509 & 0.4015965 \\
\hline & & & & \\
\hline & After & -0.18374 & -0.1188503 & 0.1897133 \\
\hline Real Estate Operations & Before & 0.560201 & 0.5679508 & 0.6032536 \\
\hline
\end{tabular}


Electric Utilities \& IPPs

$\begin{array}{llll}\text { After } & 0.002894 & -0.0627766 & 0.5509882 \\ \text { Before } & 0.732092 & 0.7564599 & 0.4449319\end{array}$

Leisure Products

$\begin{array}{llll}\text { After } & 0.298367 & 0.2867789 & 0.2994067 \\ \text { Before } & 0.715327 & 0.5778373 & 0.4716887\end{array}$

construction and Material

$\begin{array}{llll}\text { After } & 0.411567 & 0.4383869 & 0.3562319 \\ \text { Before } & 0.574192 & 0.4964117 & 0.4779782\end{array}$

$\begin{array}{lllll}\text { After } & 0.139108 & -0.0122667 & 0.4548733 \\ & \text { Before } & 0.829912 & 1.011882 & 0.4854602\end{array}$

Automobiles

$\begin{array}{llll}\text { After } & -0.01889 & -0.0339287 & 0.4146772 \\ \text { Before } & 0.927325 & 0.9058938 & 0.4156982\end{array}$

Telecommunications Services

$\begin{array}{llll}\text { After } & 0.150848 & 0.3688303 & 0.4701782 \\ \text { Before } & 0.778135 & 0.8520851 & 0.4772184\end{array}$

Electronic Equipments \& Parts
After
0.47856
0.6117964
0.4371635

Before $\quad 0.819569 \quad 0.9448312 \quad 0.3993603$

Biotechnology \& Medical Research
After
0.322480
0.404148
0.5174645
Before $\quad 0.079911$
0.1487226
0.9109253

Retailer

After $\quad-0.056630 \quad-0.2373211 \quad 0.7344444$

\subsection{Correlations}

Table 3 presents results for Pearson pair wise correlations among the variables. Several key relations become evident. The highest correlation among the control variables is 0.4883 (between variables CL and MCAP), indicating that larger firms have more than one foreign exchange listing. The correlation between SYNCH and ADIFRS is negative as expected and statistically significant at the 0.05 level with a $\mathrm{p}$ value $(0.000)$, which implies there is less stock price synchronicity after IFRS is adopted. The correlations between SYNCH\& Leverage, CL \& HERF are negative indicating firms which are more levered, listed in foreign 
exchanges and if the type of industry to which they belong is competitive, then they are less likely to follow the synchronised behaviour in terms of stock price. Correlation among other variables is below 0.10 whereas correlation among SYNCH and FS is positive; this suggests more stock price synchronicity for firms exposed to foreign sales. Moreover; ADIFRS has also positive and statistically significant correlations with MCAP with a p value (0.0077), which is consistent with evidence reported in the study of (Piotroski 2004; Fernandes \& Ferreira 2007; Ferreira \& Laux 2007). The positive coefficient on Size suggests that returns on large stocks are more synchronized with the market, relative to returns on small stocks. Also there is significant correlation between MCAP with leverage and CL which indicates mainly that the large size firms promptly go for reporting under IFRS as they are mostly listed in foreign exchanges and also less levered as compared to small firms. Below panel data analysis is performed to segregate the effect of IFRS adoption on synchronicity from the effect of other control variables.

\subsection{Panel Data Analysis}

The results of panel data analysis are reported in Table 4. There are a total of 3600(300 firms*12 years) firm year observations. The pooled OLS model fits the data well at the 05 significance level $(\mathrm{F}=10.42)$ and $\mathrm{p}<.0000) \mathrm{R}^{2}$ of 0.4051 says that this model accounts for 41 percent of the total variance in the total synchronicity values for Chinese companies. Even though this model fits the data well, we may suppose if each firm in China has different Synchronicity values by time period. That is, each firm may have its own synchronicity value, its Y-intercept that is significantly different from those of other Chinese firms. But the error term may vary by firm specific characteristics or across time period. The previous question suspect fixed effects, whereas the latter asks if there is any random effect.

Fixed effect model examines group differences in intercepts. As the analysis involves dummy variables such as $\mathrm{CL}(\mathrm{CL}=1$ when a firm is listed in foreign stock exchange and $\mathrm{CL}=0$ for not listed), ADIFRS (Adifrs=0 when IFRS was not adopted and Adifrs=1 when IFRS was adopted) and also different dummies have been assigned for different industries. The output table clearly indicates that these dummy variables are not captured by the fixed effect model. Hence we can avoid the analysis with fixed effect model. Still to confirm our selection of random effect model over fixed effect the Hausman specification test was done. In the analysis for the present study, with a Hausman test $\mathrm{Chi}^{2}$ value of 7.41 , the P-value is statistically insignificant with $\mathrm{P}>0(0.1919)$. Therefore, random effects would be more appropriate for the study. The Breusch-Pagan Lagrange multiplier (LM) test has also been performed to examine if any random effect exists. The null hypothesis is that individual-specific or time-specific error variance components are zero: $\mathrm{H} 0: \sigma 2 \mathrm{u}=0$. 
Table 3. Pearson correlation matrix for IFRS and stock price synchronicity - China

\begin{tabular}{|c|c|c|c|c|c|c|c|}
\hline & SYNCH & ADIFRS & $\operatorname{LOG}(M C A P)$ & $L E V$ & $F S A L E$ & HERF & $C L$ \\
\hline SYNCH & 1 & & & & & & \\
\hline ADIFRS & $\begin{array}{l}-0.4219 * * \\
(0.0000)\end{array}$ & 1 & & & & & \\
\hline MCAP & $\begin{array}{l}0.013 \\
(0.8413)\end{array}$ & $\begin{array}{l}0.1717 * * \\
(0.0077)\end{array}$ & 1 & & & & \\
\hline$L E V$ & $\begin{array}{l}-0.0007 \\
(0.9920)\end{array}$ & $\begin{array}{l}-0.0604 \\
(0.3517)\end{array}$ & $\begin{array}{l}-0.1488^{* *} \\
(0.0210)\end{array}$ & 1 & & & \\
\hline$F S A L E$ & $\begin{array}{l}0.0946 \\
(0.1441)\end{array}$ & $\begin{array}{l}-0.0116 \\
(0.8582)\end{array}$ & $\begin{array}{l}-0.0279 \\
(0.6660)\end{array}$ & $\begin{array}{l}-0.0218 \\
(0.7360)\end{array}$ & 1 & & \\
\hline HERF & $\begin{array}{l}-0.1544 * * \\
(0.0167)\end{array}$ & $\begin{array}{l}-0.0092 \\
(0.8871)\end{array}$ & $\begin{array}{l}0.0946 \\
(0.1430)\end{array}$ & $\begin{array}{l}-0.2484 * * \\
(0.0001)\end{array}$ & $\begin{array}{l}-0.0571 \\
(0.3783)\end{array}$ & 1 & \\
\hline$C L$ & $\begin{array}{l}-0.0448 \\
(.4894)\end{array}$ & - & $\begin{array}{l}0.4883 * * \\
(0.0000)\end{array}$ & $\begin{array}{l}-0.0745 \\
(0.2500)\end{array}$ & $\begin{array}{l}-0.1396 * * \\
(0.0306)\end{array}$ & $\begin{array}{l}0.1173 \\
(0.0690)\end{array}$ & 1 \\
\hline
\end{tabular}

Note: $* *=$ Coefficients with a p-value of .05 or lower. Notes: SYNCH -Synchronicity of firm-level stock returns with market-wide and industry- level returns. ADIFRS refers to Adoption of IFRS, dummy variable equal to 1 if a firm adopts IFRS and 0 otherwise. MCAP (Market Capitalisation) -the market value of equity of the firm at the beginning of the calendar year. $L E V G$ (Leverage) - the ratio of the long-term and short-term debts to Total Assets. F SALE - Percentage of foreign sales. $C L-$ A dummy variable for a firm's exposure to foreign capital markets, $H E R F$-A revenue-based Herfindahl index of industry-level concentration 


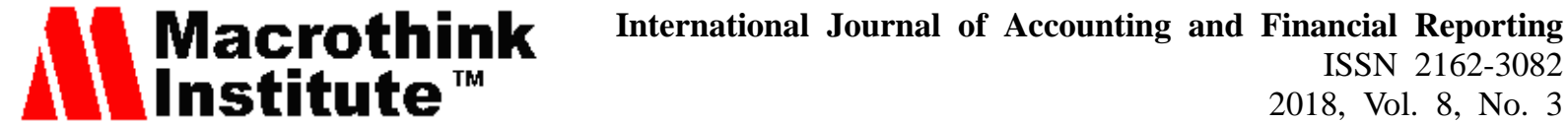

Table 4. Impact of IFRS on stock price synchronicity in China: panel data evidence

\begin{tabular}{|c|c|c|c|}
\hline VARIABLES & $\begin{array}{l}\text { POOLED } \\
\text { OLS }\end{array}$ & $\begin{array}{l}\text { FIXED } \\
\text { EFFECT } \\
\text { MODEL }\end{array}$ & $\begin{array}{l}\text { RANDOM } \\
\text { EFFECT MODEL }\end{array}$ \\
\hline \multirow{2}{*}{ CONSTANT } & -0.0686 & -0.0973 & -0.1478 \\
\hline & $(0.9000)$ & $(0.9140)$ & $(0.8130)$ \\
\hline \multirow{2}{*}{ ADIFRS } & $-0.5341 * *$ & $-0.5135 * *$ & $-0.5287 * *$ \\
\hline & $(0.0000)$ & $(0.0000)$ & $(0.0000)$ \\
\hline \multirow{2}{*}{ MCAP } & $0.1394 * *$ & 0.0737 & 0.1219 \\
\hline & $(0.0270)$ & $(0.5800)$ & $(0.1090)$ \\
\hline \multirow{2}{*}{ LEV } & -0.0026 & -0.004 & -0.0029 \\
\hline & $(0.2000)$ & $(0.3120)$ & $(0.2320)$ \\
\hline \multirow{2}{*}{ FSALE } & 0.0019 & $0.0108 * *$ & 0.0036 \\
\hline & $(0.4050)$ & $(0.0140)$ & $(0.1810)$ \\
\hline \multirow{2}{*}{ HERF } & 0.0006 & 0.0007 & 0.0006 \\
\hline & $(0.3340)$ & $(0.2420)$ & $(0.2980)$ \\
\hline \multirow[b]{2}{*}{$\mathrm{CL}$} & $-0.3053 * *$ & & -0.2991 \\
\hline & $(0.0080)$ & - & $(0.0480)$ \\
\hline \multirow[b]{2}{*}{ F-Test } & 10.42 & 14.07 & 86.82 \\
\hline & $(0.000)$ & $(0.000)$ & $(0.000)$ \\
\hline R-Square & 0.4051 & 0.3736 & 0.5532 \\
\hline Sigma_u & & & 0.1894766 \\
\hline$\theta$ & & & 0.13550569 \\
\hline
\end{tabular}


Hausman Test

Breusch and Pagan

Lagrangian

Multiplier Test

0.0067

Industry Dummies

Included

Year Dummies

Included

$\mathrm{N}$

3600

3600

3600

Note: $* *=$ Coefficients with a p-value of .05 or lower

If the null hypothesis is not rejected, the pooled OLS is preferred; otherwise, the random effect model is better. With the chi-squared value of 6.10 , and significant value of $\mathrm{p}(\mathrm{p}$ $<.0000$ ), the null hypothesis is rejected in favour of the random group effect model. Finally from the above confirmatory tests the analysis with Random effect model only is done. The Random effect model fits the data well at the .05 significance level $(F=86.82)$ and $p<.0000)$. $(\theta)$ Represents the ratio of individual specific error variance to the composite (entire) error variance; that is, $0.13550569=.1894766^{2} /\left(.1894766^{2}+.47853^{2}\right)$. This implies that individual specific errors of the dataset can explain in detail the entire composite error variances. This ratio can be interpreted as goodness-of fit for random effect model. $\mathrm{R}^{2}$ of 0.5532 says that this model accounts for 55 percent of the total variance in the Stock Price Synchronicity values for Chinese companies. Plugging in the coefficients into the above model, we have:

SYNCH= -0.1478331-0.5287782 ADIFRS+.0.1219002 log (M Cap) -0.002915Leverage

$$
+0.0036577 \text { Foreign Sale +0.0000677 Herf-0.2991086 CL +0.0046Industry }
$$

The p-values in parenthesis below each coefficient variable are the results of t-tests for individual parameters. Even in case of zero adoption, zero market capitalisation, and etc i.e. assuming no other factors impact the dependent variable i.e. Stock Price Synchronicity Chinese companies are expected to have a value of- 0.1478331 which is significant at $(\mathrm{p}<.0000)$. We can interpret from the results that when IFRS was adopted by the Chinese firms in the period 2008-2013, holding all other variables constant ,the synchronicity values get decreased by 0.5287782 units with a signifance $\mathrm{p}$ value less than $0.05(\mathrm{p}<.0000)$. The next significant variable impacting Synchronicity is CL (Foreign Listing) with $\mathrm{p}<.0000$ ). The results indicates that synchronicity value decreases for the firms which are listed in foreign stock exchanges. But all other variables such as firm size, percentage of foreign sale, Herfindhal index, leverage ratio and industry specific factors do not have any significant influence on Stock Price synchronicity with a $\mathrm{p}$ value much higher than 0.05 . 


\section{Al Macrothink}

International Journal of Accounting and Financial Reporting

\subsection{Robustness Test}

A financial tsunami hit the market hard during the late 2008-2009 period. There is a possibility that this stock market crash could affect the calculation of synchronicity in the capital market of China. Additional robustness checks are done to isolate the effect of the Asian financial crisis of 2008-09 from our findings on Impact of IFRS on stock synchronicity. (Table 5) provides the results for the robustness test after excluding the periods of 2008 and 2009 observations to see if the earlier results are unduly influenced by the Asian financial crisis. We find that the new results in are qualitatively similar to those reported in Table 4 , suggesting that our main regression results are unlikely to be driven by any external shock caused by the crisis.

Table 5. The results of robustness checks for financial crisis excluding the data for 2008 \& 2009

\begin{tabular}{ll}
\hline & CHINA \\
\hline CONSTANT & -0.0054 \\
& $(0.2742)$ \\
ADIFRS & -0.7821 \\
& $(0.0051)$ \\
LOG $(M C A P)$ & 0.359 \\
& $(0.7215)$ \\
LEV & -0.0052 \\
& $(0.1359)$ \\
& 0.011
\end{tabular}

HERF

0.1178

(0.5021)

$C L$

(0.0021) 
F-test

Havinan Test

Breusch and Pagan Lagrangian multiplier test

Industry Dummies

Included

Year Dummies

Included

$\mathrm{N}$

1200

Note: Table Above places an asterisk $(* *)$ next to the coefficients only when the p-value is .05 or lower. The numbers in parenthesis below each coefficient variable are the p-values

\subsection{Industry Synchronicity}

This section examines if the impact was homogeneous post-IFRS across industries. Prior research on the value relevance of accounting information suggests that the impact of IFRS is associated with the rate of change in particular industry environments (e.g. Francis and Schipper, 1999). Results as reported in Table 6 reports a pattern of decrease in stock price synchronicity after adoption of IFRS is different for different industries taken for analysis. Aerospace \& Defense, Automobiles Beverages, Metals \& Mining, Retailer\& Real Estate Operations have reduced synchronicity. In a demand elastic industry more reliant on market wide impacts, the quality of individual accounting reports may play an important information role in increasing market wide comparability and information flow. In contrast industries such as Biotech, Electric utilities, Electronic, Leisure products, Renewable energy and Telecom have increased synchronicity. For these industries, the low reliance on market wide information makes reasonable economic sense because they have relatively low demand elasticity. Hence, in demand inelastic industries, future price sensitive factors remain constant and so a changed IFRS accounting regime has little marginal impact. 
Table 6. Impact of IFRS on stock price synchronicity in China: panel data evidence by industry

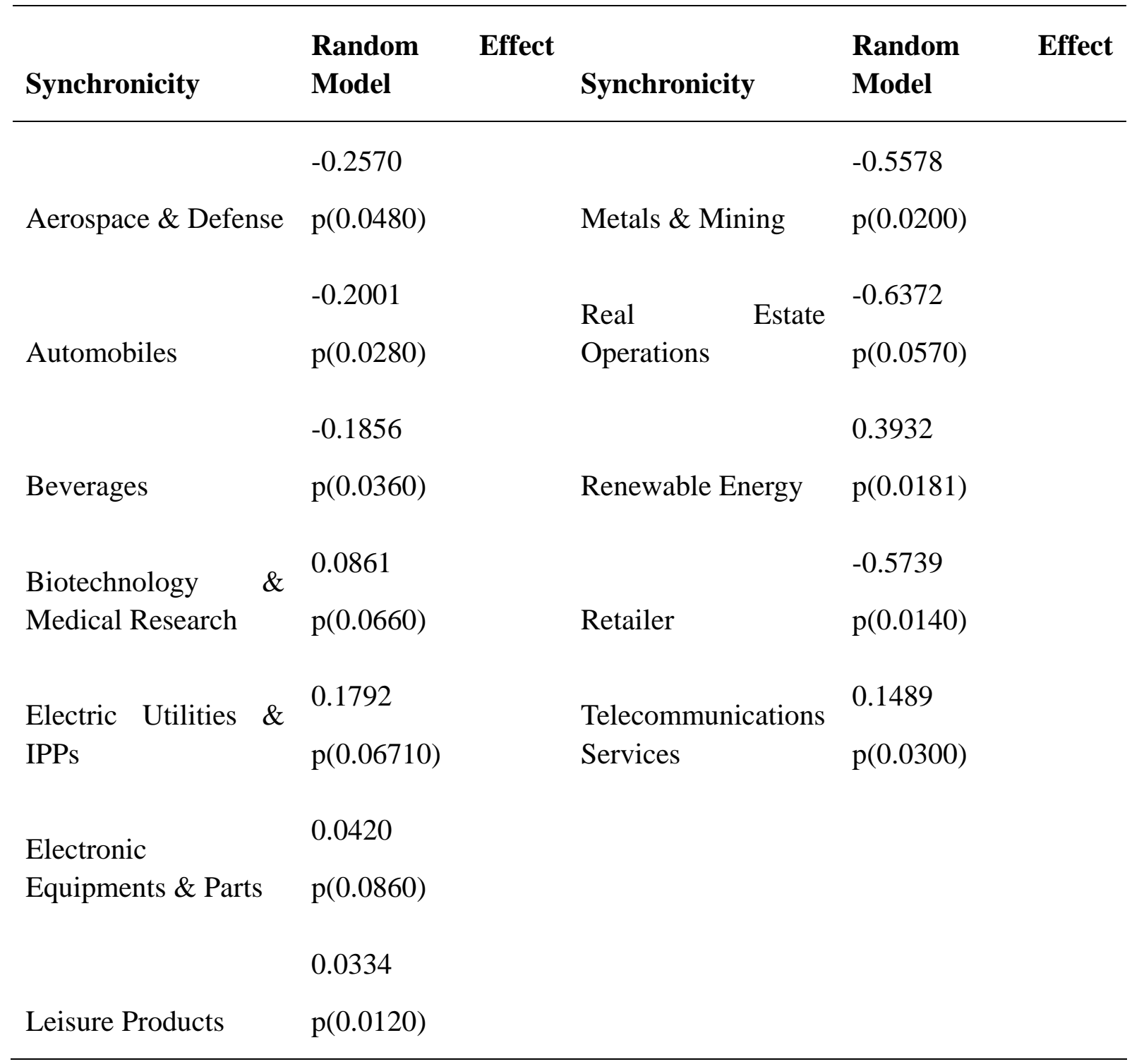

\section{Summary and Conclusion}

The stock price synchronicity exhibits a sudden decreasing pattern in the years 2008-2013 when mandatory IFRS adoption became effective as compared with the years 2001-2006 when National GAAP was effective in China. This supports the first hypothesis for China that after adoption of IFRS, stock synchronicity decreases or in other words the firm specific information is truly reflected in the stock price. Aerospace \& Defence, Automobiles Beverages, Metals \& Mining, Retailer\& Real Estate Operations have reduced synchronicity. May be in these industries the competition for external capital is greater and where firms are expected to have greater incentives to provide more informative disclosures under IFRS-converged CAS. In contrast industries such as Biotech, Electric utilities, Electronic, Leisure products, Renewable energy and Telecom have increased synchronicity. Finally to conclude the findings for China, it is evident from the results that IFRS adoption had significant influence on stock price synchronicity, but other control variables such as firm 
size, percentage of foreign sales, Herfindhal index, leverage ratio do not have any significant influence.

The study would contribute to the continuous debate on the economic and informational consequences of changes in accounting standards in different countries. As such, the study adds to the value relevance debate and provides evidence as to whether the nature of the accounting system employed really matters, to share price determination with regard to the adoption of IFRS. Another contribution of this study is to observe whether IFRS adoption affected sectors within each country. The findings help us understand one factor that can contribute to stock price i.e., the role of financial reporting standards. This research has several implications. First, it will assist the investors to better understand the role of financial reporting for making financial investment decisions. Second, it motivates the standard-setting bodies in those countries, where the adoption of IFRSs is not compulsory, to consider adoption of IFRSs, which will lead to more convergence of accounting standards all over the world and more benefits to all participants in capital markets. After the adoption of a new standard i.e. IFRS in a country, its regulators, practitioners, and academicians would be more interested in the consequences for the firms and the country as a whole, the present findings would help them with such information. The outcome may bring important implications for the regulators, practitioners, academicians and auditors, as well as end-users of financial statements. Regulators would get information about consequences on stock price information from this study to supplement their own supervision.

\section{References}

Beuselinck, C. A. C., Joos, P., Khurana, I. K., \& Van der Meulen, S. (2010). Mandatory IFRS reporting and stock price informativeness. Tilburg University.

Bissessur, S., \& Hodgson, A. (2012). Stock market synchronicity -an alternative approach to assessing the information impact of Australian IFRS. Accounting \& Finance, 52(1), 187-212.

Campbell, D., Shrives, P., \& Bohmbach - Saager, H. (2001). Voluntary disclosure of mission statements in corporate annual reports: signaling what and to whom? Business and Society Review, 106(1), 65-87.

Chan, K., \& Hameed, A. (2006). Stock price synchronicity and analyst coverage in emerging markets. Journal of Financial Economics, 80(1), 115-147.

Chua, W. F., \& Taylor, S. L. (2008). The rise and rise of IFRS: An examination of IFRS diffusion. Journal of Accounting and Public Policy, 27(6), 462-473.

Dasgupta, S., Gan, J., \& Gao, N. (2010). Transparency, price informativeness, and stock return synchronicity: Theory and evidence. Journal of Financial and Quantitative Analysis, 45(5), 1189-1220.

Dasgupta, S., Gan, J., \& Gao, N. (2010). Transparency, price informativeness, and stock return synchronicity: Theory and evidence. Journal of Financial and Quantitative Analysis, 45(05), 1189-1220.

Daske, H., Hail, L., Leuz, C., \& Verdi, R. (2008). Mandatory IFRS reporting around the world: Early evidence on the economic consequences. Journal of Accounting Research, 46(5), 1085-1142. 


\section{Macrothink}

International Journal of Accounting and Financial Reporting

ISSN 2162-3082

Durnev, A., Li, K., Mørck, R., \& Yeung, B. (2004). Capital markets and capital allocation: Implications for economies in transition. Economics of Transition, 12(4), 593-634.

Fernandes, N., \& Ferreira, M. A. (2009). Does international cross-listing improve the information environment?. Journal of Financial Economics, 88(2), 216-244.

Ferreira, M. A. \& Laux, P. A. (2007). Corporate governance, idiosyncratic risk, and information flow. The Journal of Finance, 62(2), 951-989.

Gordon, M. J., \& Shapiro, E. (1956). Capital equipment analysis: the required rate of profit. Management Science, 3(1), 102-110.

Gul, F. A., Kim, J.-B., \& Qiu, A. A. (2010). Ownership concentration, foreign shareholding, audit quality, and stock price synchronicity: Evidence from China. Journal of Financial Economics, 95(3), 425-442.

Hawksworth, J., \& Tiwari, A. (2011). The World in 2050: The accelerating shift of global economic power: challenges and opportunities. $P W C$.

Horton, J., Serafeim, G., \& Serafeim, I. (2013). Does Mandatory IFRS Adoption improve the information environment?. Contemporary Accounting Research, 30(1), 388-423

Jin, L., \& Myers, S. C. (2006). R2 around the world: New theory and new tests. Journal of Financial Economics, 79(2), 257-292.

Kelly, P. (2005). Information efficiency and firm-specific return variation. EFA 2005 Moscow Meetings Paper.

Kim, J.-B., \& Shi, H. (2012). Voluntary IFRS adoption, analyst coverage, and information quality: International evidence. Journal of International Accounting Research, 11(1), 45-76.

Kim, J.-B., \& Shi, H. (2012a). IFRS reporting, firm-specific information flows, and institutional environments: international evidence. Review of Accounting Studies, 17(3), 474-517.

Landsman, W. R., Maydew, E. L., \& Thornock, J. R. (2012). The information content of annual earnings announcements and mandatory adoption of IFRS. Journal of Accounting and Economics, 53(1), 34-54.

Lee, E., Walker, M., \& Zeng, C. (2013). Does IFRS Convergence Affect Financial Reporting Quality in China?. ACCA Research Report No. 131.

Levine, R., \& Zervos, S. (1998). Stock markets, banks, and economic growth. American Economic Review, 537-558.

Li, S. (2010). Does mandatory adoption of International Financial Reporting Standards in the European Union reduce the cost of equity capital?. The Accounting Review, 85(2), 607-636.

Liu, C., Yao, L. J., Hu, N., \& Liu, L. (2011). The impact of IFRS on accounting quality in a regulated market: An empirical study of China. Journal of Accounting, Auditing \& Finance.

Loureiro, G., \& Taboada, A. G. (2012). The impact of IFRS adoption on stock price $\begin{array}{lllll}\text { Informativeness. } & \text { Retrieved } & 05 & \text { Nov } & \text { 2013, from }\end{array}$ Http://Www.EfmaefmOrg/0efmameetings/Efma\% 20annual\%20meetings/2012 


\section{Macrothink}

International Journal of Accounting and Financial Reporting

ISSN 2162-3082

2018, Vol. 8, No. 3

Morck, R., Yeung, B., \& Yu, W. (2000). The information content of stock markets: why do emerging markets have synchronous stock price movements?. Journal of Financial Economics, 58(1), 215-260.

Nobes, C. (2006). The survival of international differences under IFRS: towards a research agenda. Accounting and Business Research, 36(3), 233-245.

Peng, M. W., Wang, D. Y., \& Jiang, Y. (2008). An institution-based view of international business strategy: A focus on emerging economies. Journal of International Business Studies, 39(5), 920-936.

Piotroski, J. D., \& Roulstone, D. T. (2004). The influence of analysts, institutional investors, and insiders on the incorporation of market, industry, and firm-specific information into stock prices. The Accounting Review, 79(4), 1119-1151.

Roll, R. (1988). R². Journal of Finance, 43(3), 541-566.

Santana, V., Sarquis, R., Lourenço, I., Salotti, B., \& Murcia, F. (2014). Economic effects of IFRS adoption in Brazil: an empirical analysis of stock price synchronicity.

Sarod, K. T. M. (2008). Empirical analysis of stock returns synchronicity a comparison of developed and emerging markets. Unpublished doctoral dissertation, RMIT University, Melbourne, Australia.

Skaife, H., Gassen, J., \& LaFond, R. (2006). Does stock price synchronicity represent firm-specific information? The international evidence. Retrieved September 15, 2009, from Papers.ssrn.com

Soderstrom, N. S., \& Sun, K. J. (2007). IFRS adoption and accounting quality: a review. European Accounting Review, 16(4), 675-702.

Wang, J., \& Yu, W. (2009). The information content of stock prices, reporting incentives and accounting standards: International evidence. Retrieved May 2, 2010, from acrobatplanet.com

\section{Note}

Note 1 . We have taken equally weighted industry level return instead of simple industry return because in some markets the economy is dominated by a very few industries and it is difficult to separate the industry effect from the market effect following (Chan \& Hameed, 2006).

\section{Copyright Disclaimer}

Copyright for this article is retained by the author(s), with first publication rights granted to the journal.

This is an open-access article distributed under the terms and conditions of the Creative Commons Attribution license (http://creativecommons.org/licenses/by/4.0/) 